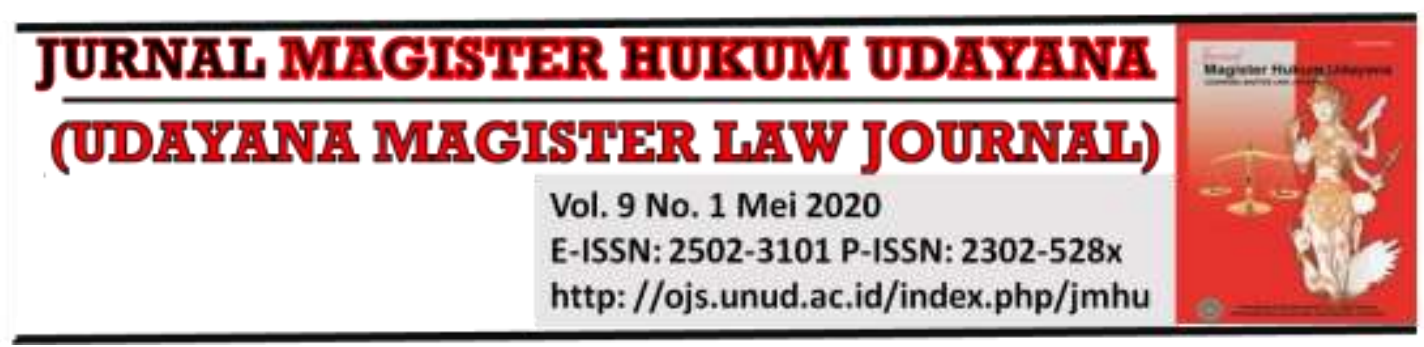

\title{
Eksistensi Pidana Mati dalam Sistem Peradilan Pidana Indonesia Perspektif Hak Asasi Manusia
}

\author{
Mochamad Sukedi ${ }^{1}$ \\ ${ }^{1}$ Program Studi Magister (S2) Ilmu Hukum Fakultas Hukum Universitas Udayana, \\ E-mail: sukedi_balindolawoffice@yahoo.com
}

\begin{tabular}{l} 
Info Artikel \\
\hline Masuk: 25 Pebruari 2020 \\
Diterima: 30 Mei 2020 \\
Terbit: 31 Mei 2020 \\
Keywords: \\
Existence; Human Rights; \\
Death Penalty \\
\\
Corresponding Author: \\
Mochamad Sukedi, Email: \\
sukedi_balindolawoffice@yahoo. \\
10.24843/JMHU.2020.v09.i01. \\
Kata kunci: \\
Pksistensi; Hak Asasi Manusia; \\
\end{tabular}

Info Artikel

2020

Keywords:

Existence; Human Rights;

Death Penalty

Kata kunci:

Eksistensi; Hak Asasi Manusia

Corresponding Author:

Mochamad Sukedi, Email.

sukedibalindolawoffice@yahoo.

\begin{abstract}
The existence of human rights is a concept that in principle is inherent in the existence and life of humans, human rights actually have a long history in which history can be traced from daily intercourse between humans. The international world knows the form of capital punishment is a type of crime that is very controversial and heaviest imposed on the perpetrators of crime so that it always raises a variety of pros and cons opinions in it. Based on this, the purpose of this paper is to find out and understand the basic legal arrangements for the death penalty in Indonesia and the application of capital punishment in the perspective of human rights. This research uses normative legal research. The death penalty is a very old type of crime that may even be as old as the existence of humanity itself. Capital punishment is the most severe type of criminal offenses of all types of basic crimes, so that capital punishment sanctions constitute a threat imposed on the perpetrators of serious crimes that have been decided by the court. In the international worldview, capital punishment is one of the most controversial forms of crime of all types of criminal sanctions in the criminal justice system in force in the world. Regarding law enforcement applied in Indonesia itself, it still applies the provisions of criminal sanctions in the Criminal Code (KUHP) and there is also listed in the Law outside the Criminal Code.
\end{abstract}

\section{Abstrak}

Keberadaan hak asasi manusia merupakan suatu konsep yang pada prinsipnya melekat pada keberadaan dan hidup manusia, hak asasi manusia sesungguhnya memiliki sejarah panjang yang mana sejarah tersebut dapat ditelusuri dari pergaulan sehari-hari antarmanusia. Dunia Internasional mengenal bentuk pidana mati adalah merupakan jenis pidana yang sangat kontroversial dan terberat dijatuhkan kepada pelaku kejahatan, sehingga selalu menimbulkan berbagai opini pro-kontra di dalamnya. Berdasarkan hal tersebut maka tujuan dalam penulisan ini yaitu untuk mengetahui dan memahami tentang pengaturan dasar hukum pidana mati di Indonesia serta penerapan pidana mati dalam perspektif hak asasi manusia. Penelitian ini menggunakan jenis penelitian hukum normatif. Sanksi pidana mati merupakan salah satu jenis pidana yang sangat tua bahkan mungkin sama tuanya dengan keberadaan umat manusia itu sendiri. Sanksi pidana mati yaitu jenis pidana yang paling berat dari segala jenis pidana pokok, sehingga sanksi pidana mati merupakan ancaman yang dikenakan kepada pelaku kejahatan berat yang telah diputus 
oleh pengadilan. Dalam pandangan dunia internasional, pidana mati adalah salah satu jenis bentuk pidana paling kontroversial dari semua jenis sanksi pidana dalam sistem peradilan pidana yang berlaku di dunia. Mengenai penegakan hukum yang diterapkan di Indonesia sendiri masih menerapkan ketentuan sanksi pidana dalam Kitab Undang-Undang Hukum Pidana (KUHP) dan ada pula yang dicantumkan di dalam Peraturan Perundang-undangan di luar KUHP.

\section{Pendahuluan}

Keberadaan hak asasi manusia merupakan suatu konsep yang pada prinsipnya melekat pada keberadaan dan hidup manusia, hak asasi manusia sesungguhnya memiliki sejarah panjang yang mana sejarah tersebut dapat ditelusuri dari pergaulan sehari-hari antarmanusia, salah satunya adalah pada saat manusia itu sadar bahwa ia adalah subjek hukum. ${ }^{1}$ Adanya Undang-Undang Dasar Negara Republik Indonesia Tahun 1945 (UUD NRI Tahun 1945) yang merupakan konstitusi Negara Indonesia di dalamnya terkandung rumusan hak asasi manusia. Memaknai konstitusi adalah social contract yang di dalamnya diberikan hak memerintah (pemerintah, penguasa) dengan yang diperintah (rakyat). ${ }^{2}$ Hak asasi manusia salah satunya berkaitan dengan yang namanya hak hidup, yang di dalam UUD NRI Tahun 1945 tertuang dalam ketentuan Pasal 28A dan 28I Ayat (1). Diaturnya hak hidup dalam ketentuan Pasal 28A dan 28I Ayat (1) UUD NRI Tahun 1945, tidak berarti implementasi pasal-pasal tersebut berjalan dengan mulus namun tetap saja adanya permasalahan yang timbul, banyaknya benturan yang terjadi antara kepentingan hukum dengan hak hidup tersebut, yaitu berkaitan dengan pemberlakuan pidana mati. Selain itu adanya permasalahan yang bertentangan dengan penghormatan dan perlindungan terhadap Hak Asasi Manusia (HAM) salah satunya terkait asas presumption of innocence dan asas self incrimination. ${ }^{3}$

Pemerintah dalam memberikan perlindungan dan pengembangan HAM di Indonesia memiliki suatu tanggungjawab dan kewajiban dalam memberikan instrumen hukum guna memberikan batasan-batasan HAM dan juga menegakkan dan melindunginya. Selain itu pemerintah pula berkewajiban untuk meratifikasi instrumen hukum internasional yang berkaitan dengan bidang HAM. ${ }^{4}$ Dunia Internasional mengenal bentuk pidana mati adalah merupakan jenis pidana yang sangat kontroversial dan terberat yang dapat dijatuhkan kepada pelaku kejahatan, sehingga selalu menimbulkan berbagai opini pro-kontra di dalamnya. Pidana mati telah diadopsi di

${ }^{1}$ Hasanah, N., \& Soponyono, E. (2018), Kebijakan Hukum Pidana Sanksi Kebiri Kimia dalam Perspektif HAM dan Hukum Pidana Indonesia. Jurnal Magister Hukum Udayana (Udayana Master Law Journal), 7(3), 305-317. doi:10.24843/JMHU.2018.v07.i03.p03, h.308.

2 Muhtaj, M.E. (2008). Dimensi-Dimensi HAM Mengurai Hak Ekonomi, Sosial, dan Budaya. Jakarta: PT.RajaGrafindo Persada. h. 61.

${ }^{3}$ Endraswari, A. (2016). Penerapan Beban Pembuktian Terbalik Dalam Perampasan Illicit Enrichment Kaitannya Dengan Hak Asasi Manusia. Jurnal Magister Hukum Udayana (Udayana Master Law Journal), 5(2), 392 - 405. doi:10.24843/JMHU.2016.v05.i02.p13, h.401.

4 Sela Septika, L. (2017). Tanggung Jawab Negara Dalam Penyelesaian Pelanggaran Hak Asasi Manusia. Jurnal Magister Hukum Udayana (Udayana Master Law Journal), 5(4), 661 - 676. doi:10.24843/JMHU.2016.v05.i04.p03, h.662. 
berbagai negara, tidak terpengaruh dengan sistem hukum Common Law ataupun Civil Law. Adapun yang melatarbelakangi pemberlakuan pidana mati di negara-negara Internasional, antara lain dikarenakan:

a. Anggapan mengenai pidana mati memiliki efektifitas yang tinggi jika dibandingkan dengan sanksi pidana lainnya, hal tersebut dikarenakan efek sanksi pidana mati yang menakutkan;

b. Secara teoritis, pidana mati juga menimbulkan efek yang sangat tinggi bagi terpidana sehingga efek jera yang didapatkan juga sangat tinggi yang menyebabkan seorang yang menjadi terpidana mati pastinya menyesal sangat dalam atas perbuatan yang dia lakukan. Sehingga sanksi pidana dapat saja menjadi alat yang prevensi umum ataupun prevensi khusus dalam ilmu hukum pidana.

Mengutip data Amnesty International yang dimuat BBC News Indonesia, pada tahun 2017 dari 193 negara anggota PBB terdapat sejumlah 142 negara di dunia yang mana telah menentukan kebijakannya untuk menghapuskan pidana mati dalam hukum positifnya masing-masing. ${ }^{5}$ Salah satu negara yang juga menghapus pidana mati dari peraturan perundang-undangannya adalah negara Belanda yang telah menghapus pidana mati sejak tahun 1982. Namun masih terdapat sejumlah 51 negara yang sampai saat ini memberlakukan pidana mati sebagai sanksi pidana terberat bagi para pelaku kejahatan berat di negaranya masing-masing. Negara-negara yang masih tetap memberlakukan pidana mati antara lain: Cina, Sudan, Amerika Serikat, Pakistan dan Indonesia. ${ }^{6}$ Selain itu data dari Amnesty International beberapa negara dengan intensitas pelaksanaan pidana mati yang sangat tinggi, antara lain:

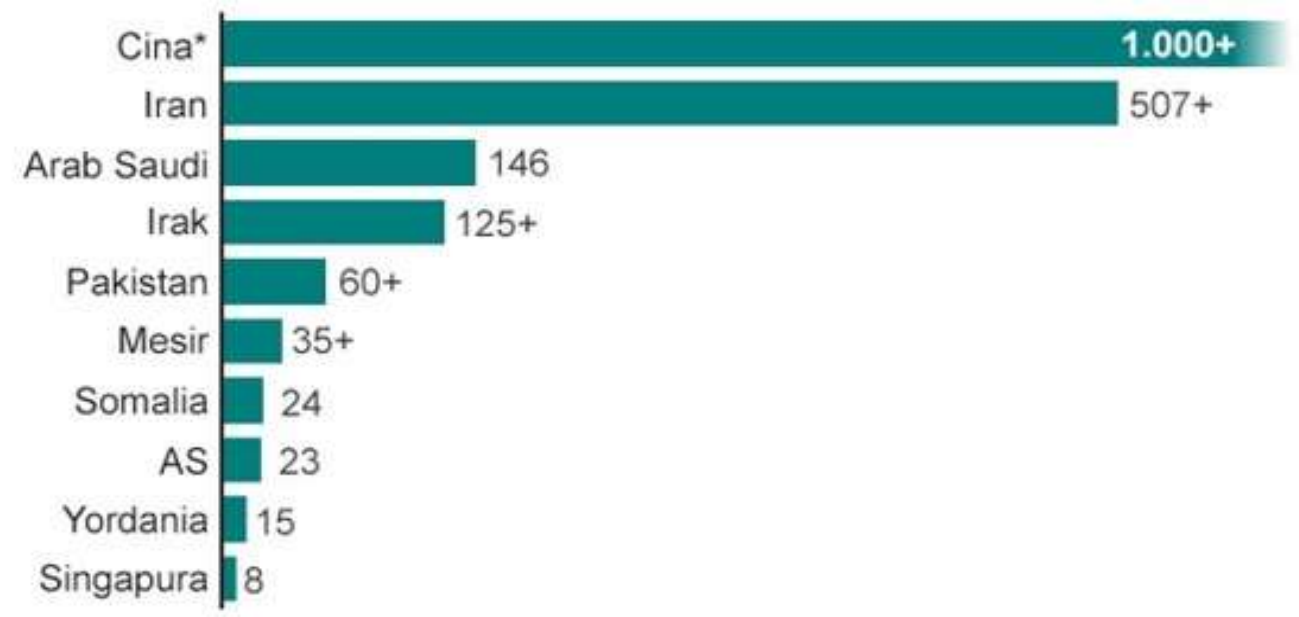

*Tak ada data resmi, namun Amnesty International memperkirakan eksekusi di Cina mencapai ribuan. Sumber : Amnesty International

Amnesty International mendasarkan statistiknya pada angka resmi, laporan media dan informasi yang disampaikan dari individu yang dijatuhi hukuman mati serta keluarga dan perwakilan mereka. Ada empat negara yang melaksanakan $84 \%$ eksekusi dunia pada 2017 (Arab Saudi, Irak, Pakistan, dan Iran). Data tersebut tidak termasuk Cina,

\footnotetext{
5 Negara Mana Yang Masih Menerapkan Hukuman Mati? Bagaimana Dengan Indonesia?, https://www.bbc.com/indonesia/dunia, (Diakses 9 Februari 2020).

${ }^{6}$ Eksekusi Mati Menurun Kecuali di China, http:/ / erabaru.net, (Diakses 7 Februari 2020).
} 
karena statistik adalah rahasia negara. Amnesty International memperkirakan bahwa Cina melakukan ribuan eksekusi setiap tahunnya.

Berkaitan dengan latar belakang yang telah penulis uraikan, dapat disampaikan rumusan masalah yang dibahas dalam penelitian ini yaitu: 1) Bagaimanakah pengaturan dasar hukum pidana mati di Indonesia? dan 2) Bagaimanakah penerapan pidana mati dalam perspektif hak asasi manusia?

Berdasarkan hal tersebut maka tujuan dalam penulisan ini yaitu guna mengetahui dan memahami tentang pengaturan dasar hukum pidana mati di Indonesia serta untuk mengetahui mengenai penerapan pidana mati dalam perspektif hak asasi manusia.

Karya tulis ini merupakan karya tulis ilmiah yang orisinal atau berbeda dengan karya tulis ilmiah yang ada sebelumnya. Adapun karya ilmiah yang terkait dengan karya tulis ilmiah penulis, yaitu karya tulis ilmiah dari 1) Muzakkir tahun 2018 dengan judul "Pidana Mati Dalam Perspektif Peradilan Di Indonesia" yang rumusan masalahnya adalah: Bagaimanakah perspektif Mahkamah Konstitusi terhadap pengujian perkara Nomor 2/PUU-V/2007 dan Perkara Nomor 3/PUU-V/2007?7 2) Iin Mutmainnah dengan judul "Pidana Mati Terhadap Pelaku Kejahatan Berat Dan Menyengsarakan" yang rumusan masalahnya adalah: Bagaimana pidana mati dalam sudut pandang perundang-undangan Indonesia? Bagaimana pidana mati dalam sudut pandang HAM Internasional? Bagaimana pidana mati menurut syari'at Islam?8 3) Amelia Arief dengan judul "Problematika Penjatuhan Hukuman Pidana Mati Dalam Perspektif Hak Asasi Manusia Dan Hukum Pidana" dengan rumusan masalah: Bagaimanakah hukuman mati dalam perspektif hak asasi manusia (HAM)? ${ }^{9}$

Berdasarkan atas uraian tersebut di atas, sangat jelas adanya perbedaan antara karya tulis atau penelitian yang ditulis penulis ini dengan penelitian atau karya tulis lainnya. Terdapat keunggulan dalam penelitian ini dengan penelitian dari peneliti lainnya, yaitu penelitian ini memfokuskan dalam pembahasan dan analisis tentang keberadaan pidana mati yang diberlakukan berdasarkan ketentuan hukum positif di Indonesia dan juga mempergunakan pandangan negara-negara Internasional berkaitan dengan prokontra pidana mati yang fokus pada pengupayaan perlindungan hak asasi manusia dan penegakan hukum yang tegas.

\section{Metode Penelitian}

Jenis penelitian yang dipergunakan dalam penelitian ini adalah jenis penelitian hukum normatif yaitu bentuk penelitian hukum yang dilaksanakan dengan meneliti bahan hukum kepustakaan dan/atau data sekunder saja. ${ }^{10}$ Adapun dalam penelitian ini mempergunakan pendekatan perundang-undangan, dan pendekatan konsep hukum.

\footnotetext{
${ }^{7}$ Muzakkir. (2018). Pidana Mati Dalam Perspektif Peradilan Di Indonesia. Jurnal Ilmu Hukum Pascasarjana Universitas Syiah Kuala 2 (2).

8 Mutmainnah, I. (2017). Pidana Mati Terhadap Pelaku Kejahatan Berat dan Menyengsarakan. Jurnal Al-Qadāu 2 (2).

9 Arief, Amelia. (2019). Problematika Penjatuhan Hukuman Pidana Mati Dalam Perspektif Hak Asasi Manusia dan Hukum Pidana. Jurnal Kosmik Hukum 19 (1).

${ }^{10}$ Soekanto, S, dan Mamudji, S. (2011). Penelitian Hukum Normatif Suatu Tinjauan Singkat, Cet. 13.

Jakarta: RajaGrafindo Persada.h. 13-14.
} 
Terdapat sumber bahan hukum yang dipergunakan dalam penelitian ini yaitu bahan hukum primer berasal dari peraturan perundang-undangan. Sedangkan bahan hukum sekunder didapatkan dari hasil berbagai penelitian, literatur berupa buku-buku dan/atau jurnal yang telah terakreditasi Nasional maupun Internasional. Analisis yang dipergunakan dalam penelitian ini yaitu analisis argumentatif, evaluatif, interpreatif dan sistematif, sehingga dapat menguraikan masalah dan menemukan solusi terhadap isu hukum yang diteliti.

\section{Hasil dan Pembahasan}

\subsection{Pengaturan Sanksi Pidana Mati Dalam Peraturan Perundang-Undangan}

Hukum pidana memiliki komponen sentral di dalamnya yang membedakan hukum pidana dengan hukum lainnya, yaitu perbuatan pidana, pertanggungjawaban pidana, serta sanksi pidana. ${ }^{11}$ Sanksi pidana mati merupakan salah satu jenis pidana yang sangat tua bahkan mungkin sama tuanya dengan keberadaan umat manusia itu sendiri. Keberadaan sanksi pidana mati juga merupakan bentuk pidana yang menarik untuk diteliti dan dikaji oleh para yuris hukum karena dalam sanksi pidana mati terkandung nilai kontradiksi atau mengenai pertentangan yang pro-kontra antara yang setuju dengan pihak yang tidak setuju. ${ }^{12}$ Adapun pihak yang setuju memberikan pemahaman bahwa pelaku kejahatan tersebut mendapatkan sanksi pidana mati dikarenakan alasan-alasan yang memang pantas dan sesuai didapatkan akibat kejahatannya. Sedangkan bagi pihak yang tidak setuju memiliki pendapat bahwa pidana mati sejak awalnya bertentangan dengan HAM yaitu tentang hak untuk hidup, yang mana merupakan alasan keberadaan dan hak dasar bagi setiap individu. Namun di beberapa negara lainnya telah menghapus pidana mati tersebut, maka tidak bagi Indonesia yang sampai saat ini masih memberlakukan pidana mati sebagai sanksi terberat bagi pelaku kejahatan. ${ }^{13}$ Teori pemidanaan yang disampaikan Van Bammelen yang bervisi lebih maju yaitu dengan tidak saja melihat pidana sebagai bentuk pemidanaan saja namun juga merupakan katerkaitan antara lembaga-lembaga pidana atau pemidanaan itu dengan makna yang ingin dicapai. ${ }^{14}$

Sebagaimana yang telah ditegaskan pada awal penelitian, penerapan pidana mati masih diberlakukan di Indonesia. Hal ini terlihat dari beberapa bentuk tindak pidana yang diancam dengan sanksi pidana mati. Sanksi pidana mati secara jelas tertulis dalam muatan materi peraturan perundang-undangan di Indonesia, bukan saja dalam ketentuan KUHP akan tetapi juga diatur di luar KUHP. Selanjutnya akan dibahas lebih detail mengenai pengaturan sanksi pidana mati dalam KUHP dan di luar KUHP.

\subsubsection{Sanksi Pidana Mati dalam Kitab Undang-Undang Hukum Pidana (KUHP)}

Bentuk kebijakan formulatif yang dipergunakan oleh legislatif dan eksekutif dalam

\footnotetext{
${ }^{11}$ Paramita Sari, A. (2017). Pertanggungjawaban Pidana Dan Pemidanaan Terhadap Pelaku Pedofilia Dalam Hukum Pidana Indonesia. Jurnal Magister Hukum Udayana (Udayana Master Law Journal), 6(1), 23 - 36. doi:10.24843/JMHU.2017.v06.i01.p03, h.24.

${ }^{12}$ Ali, M. (2012). Dasar-Dasar Hukum Pidana. Jakarta: Sinar Grafika. h.195.

${ }^{13}$ Ibid.

${ }^{14}$ Susanto, M, dan Ramdan, A. (2017). Kebijakan Moderasi Pidana Mati Kajian Putusan Mahkamah Konstitusi Nomor 2-3/PUU-V/2007. Jurnal Yudisial Fakultas Hukum Universitas Padjadjaran, Vol. 10 No. 2 Agustus 2017: 193 - 215, h.196.
} 
perumusan perundang-undangan guna menentukan perbuatan-perbuatan (tindak pidana) yang mana diancam dengan sanksi pidana mati dengan mempergunakan pendekatan yang selektif kondisional. ${ }^{15}$ Dalam KUHP pengaturan mengenai hukuman dibedakan menjadi 2 (dua), yakni jenis hukuman pokok dan jenis hukuman tambahan. Ketentuan tersebut diatur dalam Pasal 10 KUHP yang menyatakan : "Pidana terdiri dari: a. Pidana Pokok, antara lain Pidana Mati; Pidana Penjara; Pidana Kurungan; Pidana Denda, dan Pidana Tutupan; b. Pidana Tambahan, terdiri dari pencabutan hak tertentu; Perampasan barang tertentu; dan Pengumuman Keputusan Hakim."

Pengaturan delik dengan ancaman pidana mati di dalam KUHP setidaknya ada 7 (tujuh) macam jenisnya yaitu:

1. Ketentuan dalam Pasal 104 KUHP, mengenai makar kepada Presiden dan Wakil Presiden;

2. Ketentuan dalam Pasal 111 Ayat (2) KUHP, mengenai mengajak negara asing untuk menyerang pemerintahan Indonesia dalam keadaan perang;

3. Ketentuan dalam Pasal 124 Ayat (3) KUHP, mengenai memberikan pertolongan kepada pasukan musuh dalam kondisi Indonesia berperang;

4. Ketentuan dalam Pasal 140 Ayat (3) KUHP, mengenai makar kepada Raja dan/atau Presiden dan/atau Kepada Negara sahabat yang telah terencana dan/atau berakibat maut;

5. Ketentuan dalam Pasal 340 KUHP, mengenai pembunuhan berencana;

6. Ketentuan dalam Pasal 365 Ayat (4) KUHP, mengenai pencurian yang diikuti dengan kekerasan sehingga menyebabkan luka berat dan/atau mati;

7. Ketentuan dalam Pasal $444 \mathrm{KUHP}$, mengenai adanya pembajakan laut di tempat pesisir dan/atau sungai yang menyebabkan kematian.

\subsubsection{Sanksi Pidana Mati di dalam Peraturan Perundang-Undangan}

Pengaturan delik dengan ancaman pidana mati yang di atur di luar KUHP tersebar di bebarapa peraturan perundang-undangan, yaitu:

a) PERPU Nomor 21 Tahun 1959 Tentang Memperberat Ancaman Hukuman Tindak Pidana Ekonomi

Bentuk tindak pidana ekonomi (TPE), memiliki arti sempit yang diartikan bahwa tindak pidana yang dilakukan secara hukum dalam UU Darurat No. 7 Tahun 1995 Tentang Pengusutan, Penuntutan, dan Peradilan Tindak Pidana Ekonomi. 16 Pelanggaran diancam dengan hukuman yang termuat dalam Undang-Undang Darurat Nomor 7 Tahun 1955 Tentang Pengusutan, Penuntutan Dan Peradilan Tindak Pidana Ekonomi. ${ }^{17}$

b) Undang-Undang Nomor 35 Tahun 2009 Tentang Narkotika

Pengaturan pidana mati di dalam Undang-Undang Nomor 35 Tahun 2009 Tentang Narkotika (UU Narkotika) dirumuskan dalam banyak pasal dan diatur dengan

\footnotetext{
${ }^{15}$ Budiawan, I. (2017). Konsepsi Dan Aplikasi Pidana Mati Dalam Peradilan Di Indonesia. Jurnal Magister Hukum Udayana (Udayana Master Law Journal), 5(4), 711 - 727. doi:10.24843/JMHU.2016.v05.i04.p06, h.716.

${ }^{16}$ Anwar, M. (1990). Hukum Pidana di Bidang Ekonomi. Bandung: PT.Citra Aditya Bakti, h.28.

17 Ibid, h.50.
} 
sangat tegas. Terdapat 6 (enam) pasal yang mengatur pengenaan pidana mati di dalam UU Narkotika tersebut yaitu: Pasal 113 ayat (2); Pasal 114 ayat (2); Pasal 118 ayat (2); Pasal 119 ayat (2); Pasal 121 ayat (2); dan Pasal 144 ayat (2).

c) Undang-Undang Nomor 31 Tahun 1999 Jo. Undang-Undang Nomor 20 Tahun 2001 Tentang Tindak Pidana Korupsi

Pengaturan pidana mati di dalam UU Nomor 31 Tahun 1999 jo. UU Nomor 20 Tahun 2001 tentang Tindak Pidana Korupsi hanya ada 1 (satu) pasal saja yaitu pada Pasal 2 ayat (2).

d) Undang-Undang Republik Indonesia Nomor 5 Tahun 2018 Tentang Perubahan Atas Undang-Undang Nomor 15 Tahun 2003 Tentang Penetapan Peraturan Pemerintah Pengganti Undang-Undang Nomor 1 Tahun 2002 Tentang Pemberantasan Tindak Pidana Terorisme Menjadi Undang-Undang

Perumusan pidana mati yang ada di dalam UU Terorisme dicantumkan dengan sangat tegas dan jelas. Terdapat 6 (enam) pasal yang mengatur tentang pengenaan pidana mati dalam UU Terorisme yaitu: Pasal 6; Pasal 9; Pasal 10; Pasal 14; Pasal 15; dan Pasal 16.

e) Undang-Undang Nomor 26 Tahun 2000 Tentang Pengadilan Hak Asasi Manusia Dalam UU Pengadilan HAM dijabarkan secara jelas dan tegas mengenai jenis dan tingkatan pelanggaran hak asasi manusia. Di dalamnya terdapat 3 (tiga) pasal yang merumuskan pengenaan pidana mati bagi pelaku pelanggaran HAM ini, yaitu : Pasal 36; Pasal 37; dan Pasal 41.

\subsection{Eksistensi Pidana Mati Perspektif Hak Asasi Manusia (HAM) Internasional dan Nasional}

Keberadaan sanksi pidana memang sangat mustahil guna menghapuskan keberadaan kejahatan yang dilakukan oleh manusia di dunia, namun paling tidak keberadaan sanksi pidana memberikan rasa keadilan bagi para korban terhadap hal menimpanya. ${ }^{18}$ Dalam literatur hukum tidak cukup banyak ditemukan pengertian pidana mati dari para sarjana ataupun ahli hukum. Kebanyakan pengertian pidana mati ditemukan di dalam kamus bahasa, yang juga menggunakan istilah "hukuman mati". Yon Artiono Arba'i, menggunakan istilah hukuman mati dan mengartikannya dengan mengutip pengertian dari KBBI (Kamus Besar Bahasa Indonesia). Maka dapat dinyatakan bahwa pidana mati dapat dimaksudkan sebagai hukuman yang dilaksanakan dengan menghabisi pelaku yang bersalah. ${ }^{19}$ Adanya istilah mengenai pidana mati jika melihat dalam KBBI dikenal pula dengan istilah hukuman mati yang dapat dimengerti yaitu: "Pidana berupa pencabutan nyawa terhadap terpidana". ${ }^{20}$

Sanksi pidana mati yaitu jenis pidana yang paling berat dari segala jenis pidana pokok, sehingga sanksi pidana mati merupakan ancaman yang dapat dijatuhkan kepada pelaku kejahatan berat yang telah diputus oleh pengadilan. Pemberlakuan pidana mati sampai saat ini memang menimbulkan banyak pro-kontra. Pidana mati itu sendiri

${ }^{18}$ Yudiantari Darmadi, A. (2015). Kebijakan Hukum Pidana Mempertahankan Jenis Pidana Mati (Studi Kasus Pembunuhan Berencana Disertai Mutilasi Korban). Jurnal Magister Hukum Udayana (Udayana Master Law Journal), 4(3). doi:10.24843/JMHU.2015.v04.i03.p04, h.469.

${ }^{19}$ Arba'i, Y. A. (2012). Aku Menolak Hukuman Mati: Telaah Atas Penerapan Pidana Mati, Jakarta: KPG (Kepustakaan Populer Gramedia). h.66.

${ }^{20}$ Departemen Pendidikan Nasional. (2013). Kamus Besar Bahasa Indonesia Pusat Bahasa. Cetakan Ketujuh. Edisi IV. Jakarta: Gramedia Pustaka Utama, h.1071. 
memiliki sifat yang eksepsional yang bermakna bahwa pidana mati itu hanya diberlakukan atau dijatuhkan apabila hakim menilai memang benar-benar diperlukan dan telah sesuai dengan unsur-unsur kejahatan yang diatur dalam peraturan perundang-undangan.

Sebagaimana telah diketahui bahwa pemahaman dan pengetahuan umum mengenai hak asasi manusia antara satu negara dengan negara lainnya adalah berbeda. ${ }^{21}$ Apabila kita berpegang dengan prinsip dan norma yang terkandung dalam implementasi hak asasi manusia, maka seharusnya pidana mati memang wajib untuk dihapus dan ditolak pemberlakuannya atas dasar kebebasan dan kemerdekaan individu yang dijamin oleh Yang Maha Kuasa. Kebebasan, kemerdekaan adalah identik dengan sebutan diskresi akan menimbulkan problem jika kewenangan yang diberikan melampaui dan apa yang semestinya harus dilakukan sesuai aturan hukum yang telah mengaturnya. ${ }^{22}$ Biarpun beratnya kejahatan yang dilakukan oleh pelaku tidak seharusnya dikenakan sanksi pidana mati yang mencabut nyawa manusia. Bagaimana hal tersebut harus dijelaskan? Pertama, negara tidak saja memiliki kewajiban menghormati dan juga melindungi hak hidup, namun juga memiliki tanggungjawab guna melaksanakan penegakan hukum yang tidak semata-mata merenggut hak hidup.

Merupakan tugas negara untuk menjamin hak-hak mereka sebagai warga negaranya, seperti Indonesia yang menyatakan diri sebagai negara demokrasi yang berlandaskan atas hukum, sudah menjadi konsekuensi logis untuk melindungi semua rakyatnya dalam segala aspek kehidupan. ${ }^{23}$ Dengan menjamin hak setiap orang untuk hidup maka negara seharusnya tidak dapat merenggutnya dengan alasan penegakan hukum pidana saja. Kedua, mengenai prinsip hak asasi manusia, yaitu hak hidup yaitu hak yang tak terenggut, yang tidak boleh tercabut dengan keadaan atau kondisi apapun. Pencabutan hak dalam kondisi peperangan saja tidak diperkenankan, apalagi dalam kondisi yang damai. Ketiga, hak hidup yaitu hak yang melekat pada diri setiap orang. Hidup manusia itu sendiri menyatu dengan jiwa, sehingga merenggut jiwa berarti pula mengakhiri hidup manusia yang mana seharusnya hanya merupakan kewenangan Yang Maha Kuasa. Sehingga dari itu, penulis mencoba menguraikan mengenai eksistensi pidana mati dalam pandangan HAM dalam pranata Nasional dan Internasional.

\subsubsection{Eksistensi Pidana Mati Perspektif Hak Asasi Manusia (HAM) Internasional}

Menurut pandangan dunia internasional, keberadaan pidana mati yaitu mengenai salah satu jenis pemidanaan yang sangat berat dan paling kontroversial dari berbagai jenis sanksi pidana di dunia ini, pidana mati juga diimplementasikan dalam sistem

${ }^{21}$ Na Gara, I. (2016). Analisa Yuridis Pencabutan Hak Memilih Dan Dipilih Sebagai Pidana Tambahan Dalam Perspektif Perlindungan Hak Asasi Manusia Pada Putusan Ratu Atut Chosiyah. Jurnal Magister Hukum Udayana (Udayana Master Law Journal), 5(1), 131 - 148. doi:10.24843/JMHU.2016.v05.i01. p13, h.134.

${ }^{22}$ Indra Bhawana, I. (2016). Independensi Dan Impartialitas Hakim Perspektif Teoritik - Praktik Sistem Peradilan Pidana. Jurnal Magister Hukum Udayana (Udayana Master Law Journal), 5(1), 184 - 201. doi:10.24843/JMHU.2016.v05.i01.p17, h.197.

${ }^{23}$ Manik, E. (2016). Bantuan Hukum Dan Penyantunan Terpidana Perspektif Sistem Peradilan Pidana Indonesia. Jurnal Magister Hukum Udayana (Udayana Master Law Journal), 5(2), 252 - 271. doi:10.24843/JMHU.2016.v05.i02.p03, h.253. 
hukum Civil Law dan Common Law tanpa ada pembatasan mengenai hak hidup bagi terpidana. ${ }^{24}$ Adanya norma hukum pada pranata internasional, adanya dua kelompok yang juga terus mengemukakan hal yang saling bertolak belakang satu sama lainnya. Di sisi lain kelompok kontra adanya pidana mati memiliki pendapat bahwa normanorma dalam hukum internasional melarang dengan tegas pemberlakuan pidana mti. Sedangkan pada sisi lainnya kelompok pro pemberlakuan pidana mati memiliki keyakinan bahwa norma hukum internasional pada prinsipnya tidaklah melarang tentang pidana mati.

Ketentuan dalam hukum Internasional terdapat 2 (dua) instrumen yang berkaitan dengan sanksi pidana mati, yaitu instrumen hukum HAM Internasional yang merupakan perjanjian-perjanjian internasional dari Mahkamah Kejahatan Internasional. Adapun kategori pertama instrumen HAM Internasional yaitu Kovenan Internasional Hak-hak Sipil dan Politik yang telah diratifikasi oleh pemerintah Indonesia (International Covenant on Civil and Political Rights). Meski diakui hak hidup sebagai non-derogable rights (hak yang tidak dapat dikurang-kurangi), pada Pasal 6 (ayat 2, 4, dan 5) secara tekstual dinyatakan bahwa pidana mati masih diperbolehkan. Sementara itu pada Pasal 6 (ayat 6) kembali ditegaskan adanya semangat Kovenan ini untuk secara bertahap dan progresif menghapuskan praktek hukuman mati.

Kedua instrumen hukum yang selalu menjadi dasar atas pemberlakuan pidana mati di dunia Internasional yaitu :

1. Mahkamah Tribunal (Nurenberg Tribunal)

Mahkamah Tribunal (Nurenberg Tribunal) adalah peradilan militer yang diselenggarakkan oleh negara-negara pemenang Perang Dunia II untuk mengadili personil Jerman yang dianggap melakukan kejahatan Internasional selama Perang Dunia II. Persetujuan yang melandasi pelaksanaan Mahkamah Nurenberg, yakni "agreement for the prosecution and punishment of the major war criminals of the european axis" pada tanggal 8 Agustus tahun 1945 yang secara tegas memuat ancaman pidana mati;

2. ICTY (International Criminal Tribunal for the former Yugoslavia) dan ICTR (International Criminal Tribunal for Rwanda)

ICTY (International Criminal Tribunal for the former Yugoslavia) dan ICTR (International Criminal Tribunal for Rwanda) adalah dua Mahkamah Kejahatan Internasional ad-hoc yang dibentuk pada tahun 1990-an, sekitar empat dekade setelah pembentukkan Mahkamah Nurenberg. Perubahan mendasar yang terjadi diantara Mahkamah Nurenberg dengan ICTY dan ICTR, khususnya menyangkut pidana mati. Meskipun tidak secara eksplisit terdapat gagasan yang kuat di dalam statuta ICTY dan ICTR untuk menolak penerapan pidana mati. Artikel 24 Statuta ICTY dan Artikel 23 menegaskan bahwa "the penalty imposed by the trial chamber shall be limited to imprisonment" ini berarti bahwa di dalam sistem peradilan ICTY dan ICTR, pidana mati tidak akan diterapkan;

3. ICC (International Criminal Court)

Dasar penyelengaraan ICC yakni Statuta Roma 1998 yang sebelumnya sudah dimulai oleh ICTY dan ICTR terkait dengan pidana mati. Dalam artikel 77 Statuta Roma secara tegas menyatakan bahwa pidana pokok yang bisa dijatuhkan terhadap

${ }^{24}$ Hamzah, A. (2012). Pemberantasan Korupsi Melalui Hukum Pidana Nasional dan Internasional. Cetakan ke-5. Jakarta: RajaGrafindo Persada. h.65. 
pelaku Genosida (Genocide), kejahatan terhadap kemanusiaan (Crime Against Humanity), Kejahatan Perang (War Crimes), dan Kejahatan Agresi (The Crime of Agression) adalah:

"Imprisonment for a specified number of years, which may not exceed a maximum of 30 years: or A term of life imprisonment when justified by the extreme gravuty of the crime and the individual circumstances of the convicted person."

Terhadap pidana tambahan yang dapat dijatuhkan adalah:

"A fine under the criteria provided for in the rules of precudereand evidence. A forfeiture of proceeds. Property and assets derived directly or indirectly from that crimes, without prejudice to the rights of bona fide third parties." 25

Pada titik inilah situasi paradoksal bisa muncul. Jika penghapusan pidana mati seperti yang terefleksikan di dalam statuta ICTY, ICTR, dan ICC dianggap sebuah perlindungan the right to life dari pelaku kejahatan Internasional, maka perlindungan itu justru telah memberikan sebuah hak istimewa (privilege rights) kepada orang yang salah, yang justru secara kasar dan eksesif telah melanggar hak hidup (the right to life) sekian ribu orang yang menjadi korban perbuatan pelaku. Pada titik ini pula rasa keadilan bisa menjadi sangat terusik.

\subsubsection{Eksistensi Pidana Mati Perspektif Hak Asasi Manusia (HAM) Nasional}

Mengenai penegakan hukum yang diterapkan di Indonesia sendiri masih menerapkan ketentuan sanksi pidana dalam Kitab Undang-Undang Hukum Pidana (KUHP) dan ada pula tercantum dalam Peraturan Perundang-Undang di luar KUHP yang masingmasing mencantumkan pelaksanaan sanksi pidana mati bagi pelaku kejahatan. Ketentuan yang tertuang dalam KUHP sendiri merupakan terjemahan dari Wetboek van Strafrecht voor Nederlandsch-Indie yang dahulu diterapkan pada masa penjajahan kolonial Belanda di Indonesia sejak tahun 1918. Sedangkan di Belanda sendiri, yang mana merupakan asal dari sumber asli isi KUHP telah menghapus sanksi pidana mati sejak 1970. Namun Indonesia sejak memproklamirkan kemerdekaannya pada 17 Agustus 1945, dengan adanya ketentuan Pasal II Aturan Peralihan dalam UUD NRI Tahun 1945, maka bersamaan dengan itu pula sanksi pidana mati tetap diberlakukan sampai saat ini, bahkan dalam Rancangan Kitab Undang-Undang Hukum Pidana (RKUHP) yang saat ini digodok dan masih disempurnakan oleh parlemen masih saja mencantumkan sanksi pidana mati walaupun berbeda dengan ketentuan sanksi pidana mati saat ini yang masuk sebagai jenis pidana pokok, sedangkan dalam RKUHP merupakan pidana khusus dan memiliki sifat yang alternatif.

Munculnya perdebatan bukan saja para ahli hukum namun juga masyarakat mengenai apakah pelaksanaan pidana mati masih saja sesuai dan relevan dalam perkembangan penegakan hukum di Indonesia. Pertanyaan tersebut bukan saja tanpa alasan namun hal tersebut karena memang didasarkan atas ketentuan dalam konstitusi kita dalam Pasal 28A UUD NRI Tahun 1945, yang menyatakan: “Setiap orang berhak untuk hidup serta berhak mempertahankan hidup dan kehidupannya". Maka sepantasnya hak hidup harus dilindungi dan merupakan hak dasar dari Hak Asasi Manusia (HAM) itu sendiri.

${ }^{25}$ Kirchmeier, J. L. (2006) Dead Innocent: The Death Penalty Abolitionist Search for a Wrongful Execution. Tulsa Law Review. Vol.42/2006. h.2. 
Berdasarkan dengan hal tersebut di atas yang didasarkan pada Pasal 28A UUD NRI Tahun 1945, yang secara tegas menjelaskan bahwa hak hidup merupakan hak yang mendasar bagi manusia dan tidak dapat dikurangi sedikitpun dalam kondisi apapun. ${ }^{26}$ Selain didasarkan pada Pasal 28A UUD NRI Tahun 1945, mengenai Hak Asasi Manusia (HAM), Indonesia juga melindungi HAM dengan ketentuan peraturan perundang-undangan yaitu dengan diundangkannya Undang-Undang Nomor 39 Tahun 1999 Tentang Hak Asasi Manusia (selanjutnya disebut UU HAM). Di dalam UU HAM dijelaskan mengenai hak hidup dalam ketentuan Pasal 9 Ayat (1) yang menyatakan: "..... Hak mengenai kehidupan ini bahkan melekat pada bayi yang baru lahir atau orang yang terpidana mati..."

Secara sekilas pasal tersebut di atas tidak jauh dengan ketentuan Pasal 28A UUD NRI 1945 yang menyatakan: "Setiap orang berhak untuk hidup serta berhak mempertahankan hidup dan kehidupannya. Dengan adanya Putusan MK Nomor 23/PUU-V/2007 Tentang Pengujian Undang-Undang Nomor 22 Tahun 1997 Tentang Narkotika, dalam konteks hukum di Indonesia telah menjelaskan mengenai penerapan, perumusan dan pelaksanaan sanksi pidana mati dengan menegaskan 4 (empat) hal yang harus ada yaitu:

1. Sanksi pidana mati, tidak lagi bagian dari pidana pokok, namun hanya bagian dari pidana yang memiliki sifat alternatif dan khusus;

2. Sanksi pidana mati yang diputuskan kepada pelaku kejahatan dapat dilakukannya masa percobaan selama 10 (sepuluh) tahun yang didasarkan apabila terpidana berkelakuan baik dan sesuai dengan syarat-syarat yang ditentukan maka sanksi pidana mati dapat diubah menjadi pidana penjara seumur hidup atau sanksi penjara 20 (dua puluh) tahun;

3. Sanksi pidana mati tidak dapat diputuskan atau dijatuhkan terhadap subjek hukum yang belum cakap hukum (anak) sebelum ia dewasa;

4. Mengenai pelaksanaan (eksekusi) pidana mati kepada seorang wanita yang masih hamil dan kepada orang yang masih gangguan jiwa ditangguhkan sampai dengan wanita tersebut melahirkan dan terpidana yang sakit jiwa telah sembuh. ${ }^{27}$

Dalam ketentuan RUU KUHP, mengenai sanksi pidana mati memiliki sifat yang khusus dan diancam dengan sanksi yang alternatif. Namun walaupun tidak dimasukkan sebagai pidana pokok, tetap saja terdakwa dapat direnggut hak hidupnya.

\section{Kesimpulan}

Pengaturan dasar hukum pidana mati di Indonesia diatur dalam Pasal 10 KUHP mengenai jenis-jenis hukuman pidana yang menyatakan pidana pokok salah satunya adalah Pidana Mati. Pengaturan delik dengan ancaman pidana mati di dalam KUHP setidaknya ada 7 (tujuh) macam jenisnya yaitu: Ketentuan dalam Pasal 104 KUHP, Pasal 111 Ayat (2) KUHP, Pasal 124 Ayat (3) KUHP, Pasal 140 Ayat (3) KUHP, Pasal

\footnotetext{
${ }^{26}$ Lubis, T. M., dan Lay, A. (2009). Kontroversi Hukuman Mati Perbedaan Pendapat Hakim Konstitusi. Jakarta: Kompas Media Group. h.98.

${ }^{27}$ Lihat Putusan MK Nomor 2-3/PUU-V/2007 Tentang Pengujian Undang-Undang Nomoru22 Tahun 1997 Tentang Narkotika.
} 
340 KUHP, Pasal 365 Ayat (4) KUHP, Pasal 444 KUHP. Ada pula pengaturan delik dengan ancaman pidana mati yang diatur di luar KUHP tersebar di beberapa peraturan perundang-undangan, yaitu: PERPU Nomor 21 Tahun 1959 Tentang Memperberat Ancaman Hukuman Tindak Pidana Ekonomi, Undang-Undang Nomor 35 Tahun 2009 Tentang Narkotika, Undang-Undang Nomor 31 Tahun 1999 Jo. Undang-Undang Nomor 20 Tahun 2001 Tentang Tindak Pidana Korupsi, UndangUndang Republik Indonesia Nomor 5 Tahun 2018 Tentang Perubahan Atas UndangUndang Nomor 15 Tahun 2003 Tentang Penetapan Peraturan Pemerintah Pengganti Undang-Undang Nomor 1 Tahun 2002 Tentang Pemberantasan Tindak Pidana Terorisme Menjadi Undang-Undang, dan Undang-Undang Nomor 26 Tahun 2000 Tentang Pengadilan Hak Asasi Manusia.

Penerapan pidana mati dalam perspektif hak asasi manusia, bila didasarkan pada Pasal 28A UUD NRI Tahun 1945, yang secara tegas menjelaskan bahwa hak hidup merupakan hak yang mendasar bagi manusia dan tidak dapat dikurangi sedikit pun dalam kondisi apapun. Namun pelaksanaan sanksi pidana mati dapat dilaksanakan dengan menegaskan yaitu: 1) penerapannya hanya bisa berlaku bagi kejahatan yang paling serius, yang kategorinya harus sesuai dengan tingkat konsekuensi yang sangat keji; 2) Pidana mati hanya boleh berlaku bila kejahatan tersebut tercantum dalam produk hukum tertulis yang tidak bisa bersifat retroaktif (berlaku surut) pada saat kejahatan tersebut dilakukan; 3) Pidana mati tidak boleh diterapkan pada anak yang berusia 18 tahun pada saat ia melakukan kejahatan tersebut, tidak boleh diterapkan kepada perempuan yang sedang hamil atau ibu yang baru melahirkan. Hukuman mati tidak boleh dijatuhkan kepada orang yang cacat mental atau gila; 4) Seseorang yang dijatuhi pidana mati berhak untuk mengajukan pengampunan atau perubahan hukuman. Hal ini harus mencakup semua jenis kejahatan; dan 5) Ketika eksekusi mati dijalankan, metodenya harus seminimal mungkin menimbulkan penderitaan.

\section{Daftar Pustaka}

\section{Buku}

Ali, M. (2012). Dasar-Dasar Hukum Pidana. Jakarta: Sinar Grafika.

Anwar, M. (1990). Hukum Pidana di Bidang Ekonomi. Bandung: PT.Citra Aditya Bakti.

Arba'I, Y. A. (2012). Aku Menolak Hukuman Mati: Telaah Atas Penerapan Pidana Mati, Jakarta: KPG (Kepustakaan Populer Gramedia).

Departemen Pendidikan Nasional. (2013). Kamus Besar Bahasa Indonesia Pusat Bahasa. Cetakan Ketujuh. Edisi IV. Jakarta: Gramedia Pustaka Utama.

Hamzah, A. (2012). Pemberantasan Korupsi Melalui Hukum Pidana Nasional dan Internasional. Cetakan ke-5. Jakarta: RajaGrafindo Persada.

Lubis, T. M., dan Lay, A. (2009). Kontroversi Hukuman Mati Perbedaan Pendapat Hakim Konstitusi. Jakarta: Kompas Media Group.

Muhtaj, M.E. (2008). Dimensi-Dimensi HAM Mengurai Hak Ekonomi, Sosial, dan Budaya. Jakarta: PT.RajaGrafindo Persada.

Soekanto, S., dan Mamudji, S. (2011). Penelitian Hukum Normatif Suatu Tinjauan Singkat, Cet. 13. Jakarta: RajaGrafindo Persada.

\section{Jurnal}

Arief, Amelia. (2019). Problematika Penjatuhan Hukuman Pidana Mati Dalam Perspektif Hak Asasi Manusia Dan Hukum Pidana. Jurnal Kosmik Hukum 19 (1). 
Bhawana, I. G. W. I. (2016). Independensi dan Impartialitas Hakim Perspektif TeoritikPraktik Sistem Peradilan Pidana. Jurnal Magister Hukum Udayana (Udayana Master Law Journal), 5(1), 184-201. ttps://doi.org/10.24843/JMHU.2016.v05.i01.p17

Budiawan, I. M. P. (2016). Konsepsi dan Aplikasi Pidana Mati Dalam Peradilan Di Indonesia. Jurnal Magister Hukum Udayana (Udayana Master Law Journal), 5(4), 711-727. https:// doi.org/10.24843/JMHU.2016.v05.i04.p06

Darmadi, A. S. M. Y. (2015). Kebijakan Hukum Pidana Mempertahankan Jenis Pidana Mati (Studi Kasus Pembunuhan Berencana Disertai Mutilasi Korban). Jurnal Magister Hukum Udayana (Udayana Master Law Journal), 4(3). 464-474. https://doi.org/10.24843/JMHU.2015.v04.i03.p04

Endraswari, A. M. (2016). Penerapan Beban Pembuktian Terbalik Dalam Perampasan Illicit Enrichment Kaitannya Dengan Hak Asasi Manusia. Jurnal Magister Hukum Udayana (Udayana Master Law Journal), 5(2), 392-405. https://doi.org/10.24843/JMHU.2016.v05.i02.p13

Gara, I. W. D. N. (2016). Analisa Yuridis Pencabutan Hak Memilih dan Dipilih Sebagai Pidana Tambahan Dalam Perspektif Perlindungan Hak Asasi Manusia Pada Putusan Ratu Atut Chosiyah. Jurnal Magister Hukum Udayana (Udayana Master Law Journal), 5(1), 131-148. https://doi.org/10.24843/JMHU.2016.v05.i01.p13

Hasanah, N. H., \& Soponyono, E. (2018). Kebijakan Hukum Pidana Sanksi Kebiri Kimia dalam Perspektif HAM dan Hukum Pidana Indonesia. Jurnal Magister Hukum Udayana (Udayana Master Law Journal), 7(3), 305-317. https://doi.org/10.24843/JMHU.2018.v07.i03.p03

Kirchmeier, J. L. (2006). Dead Innocent: The Death Penalty Abolitionist Search for a Wrongful Execution. Tulsa Law Review, 42(2), 403-436.

Manik, E. H. (2016). Bantuan Hukum Dan Penyantunan Terpidana Perspektif Sistem Peradilan Pidana Indonesia. Jurnal Magister Hukum Udayana (Udayana Master Law Journal), 5(2), 252-271. https://doi.org/10.24843/JMHU.2016.v05.i02.p03

Mutmainnah, I. (2015). Pidana Mati Terhadap Pelaku Kejahatan Berat dan Menyengsarakan. Jurnal Al-Qadau: Peradilan dan Hukum Keluarga Islam, 2(2), 209221. https:// doi.org/10.24252/al-qadau.v2i2.2643

Muzakkir, F. A. R., \& Ali, D. (2014). Pidana Mati Dalam Perspektif Peradilan Di Indonesia. Jurnal Ilmu Hukum, 2(2). 67-76.

Sari, A. A. A. S. P. (2017). Pertanggungjawaban Pidana dan Pemidanaan Terhadap Pelaku Pedofilia Dalam Hukum Pidana Indonesia. Jurnal Magister Hukum Udayana (Udayana Master Law Journal), 6(1), 23-36. https://doi.org/10.24843/JMHU.2017.v06.i01.p03

Septika, L. P. S. (2016). Tanggung Jawab Negara Dalam Penyelesaian Pelanggaran Hak Asasi Manusia. Jurnal Magister Hukum Udayana (Udayana Master Law Journal), 5(4), 661-676. https://doi.org/10.24843/JMHU.2016.v05.i04.p03

Susanto, M., \& Ramdan, A. (2017). Kebijakan moderasi pidana mati. Jurnal Yudisial, 10(2), 193-215.

\section{Online/ World Wide Web}

Era Baru. Eksekusi Mati Menurun Kecuali di China, http://erabaru.net , diakses 7 Februari 2020.

BBC. Negara Mana Yang Masih Menerapkan Hukuman Mati? Bagaimana Dengan Indonesia?, https://www.bbc.com/indonesia/dunia-45859508, diakses 9 Februari 2020. 


\section{Peraturan Perundang-Undangan}

Undang-Undang Dasar Negara Republik Indonesia Tahun 1945.

Undang-undang Nomor 39 Tahun 1999 Tentang Hak Asasi Manusia. Lembaran Negara Nomor 165 Tahun 1999. Tambahan Lembaran Negara Nomor 3886. 